SHORT COMMUNICATION Sokoto Journal of Veterinary Sciences

\title{
Perspectives of animal health workers in Nigeria to global eradication of peste des petits ruminants (PPR)
}

\author{
YA Alimi ${ }^{1}$, AM Adamu ${ }^{2}$, JS Akinbobola ${ }^{3}, \mathrm{MZ} \mathrm{Wunti}{ }^{4} \& \mathrm{~K} \mathrm{Mohammed}^{4}$ \\ 1. Department of Veterinary Physiology and Biochemistry, Faculty of Veterinary Medicine, University of Abuja, Nigeria \\ 2. Department of Veterinary Public Health and Preventive Medicine, Faculty of Veterinary Medicine, University of Abuja, Nigeria \\ 3. Veterinary Teaching Hospital, University of Abuja, Nigeria \\ 4. National Animal Production Research Institute, Zaria, Nigeria
}

*Correspondence: Tel.: +2348052630835; E-mail: jonesakinbobola@gmail.com

\begin{abstract}
Copyright: (c) 2018 Alimi et al. This is an open-access article published under the terms of the Creative Commons Attribution License which permits unrestricted use, distribution, and reproduction in any medium, provided the original author and source are credited.
\end{abstract}

Publication History: Received: 21-11- 2017 Accepted: 20-03-2018

\section{Abstract}

The Food Agriculture Organization - Office International des Epizooties (FAO-OIE) coordinated global eradication program, launched in 2015 , is expected to help stamp out pestes des petits ruminants (PPR) from across the world by the year 2030. A questionnaire survey was employed to assess the perception of animal healthcare workers about the possibility of PPR elimination in the country, using FAO-OIE strategy. A total of four hundred and forty six (446) animal health workers participated in the survey, out of which 126 (28.25\%) considered PPR the most important small ruminant disease. Despite the history of disease endemicity in Nigeria, only $40 \%$ of animal health workers have received PPR vaccination request since they began practice. Result also showed that $58 \%$ of study respondents were aware of the ongoing FAO-OIE global eradication programme against PPR, with their information sources being internet $(55 \%)$, professional colleagues $(32 \%)$ radio, print media (12\%) and television (1\%). Respondents were of the opinion that PPR eradication and control was the sole responsibility of animal health workers (67\%), veterinarians (29\%), technologists (4\%) and government (0\%). To achieve disease eradication in Nigeria by year 2030, the focal areas that need urgent attention are veterinary infrastructure, vaccine production, disease diagnosis, surveillance and notification.

Keywords: Animal health workers, Awareness, Global eradication, Nigeria, Perspective, PPR

\section{Introduction}

Since the eradication of rinderpest, there has been widespread optimism over the possible eradication of yet another important livestock disease peste des petits ruminants (PPR); which is a close relative of rinderpest, known to cause a devastation in small ruminants (Anderson et al., 2011; Baron et al., 2011; Albina et al., 2013). However, this will not happen until some important challenges are tackled and overcome by all major stakeholders (Baron et al., 2011). In March - April 2015, the World Organization for Animal Health (OIE) and United Nations Food and
Agriculture Organization (FAO) jointly decided to embark upon a 'PPR Global Control and Eradication Strategy', (hereinafter named 'Global Strategy') with a strong willingness to address the animal health problems in a systematic way through approaching horizontal as well as more disease-specific (vertical) issues (FAO - OIE, 2015). The first phase is to last for 3 years and has the ultimate goal of developing and launching effective PPR eradication programmes at the international, regional and national levels. In the 5 - year phase 2, there are intensive targeted vaccination programmes and appropriate 
epidemiological studies, carried out in infected countries to eradicate PPR virus. At the end of this phase, there would have been a global elimination of PPR virus from its natural hosts in the field. At phase 3 which is meant to last for 4 years, there is a systematic and scientific validation of the global eradication of PPR by demonstrating the absence of PPR infection and preparing evidence for OIE accreditation of disease free status on a country-bycountry basis. Upon freedom from PPR, there will be a 3-year post-eradication phase for PPR virus sequestration, post-eradication surveillance and emergency response and documentation of lessons learned for future eradication and disease control programmes. The overall goal of this global strategy was to gain more information, control, and finally eradicate PPR by 2030 in a similar way that was done with rinderpest (Torsson et al., 2016). Currently, Nigeria has some targeted interventions aimed at controlling or eliminating the disease (Fadiga et al., 2013). While some information is available in the literature about the epidemiological nature and pattern of PPR occurrence globally, there is dearth of information on how important PPR is to animal health workers in Nigeria and what opinions they hold about existing challenges against current disease elimination in Nigeria. To fill these knowledge gaps, this study aims to investigate the awareness and perspectives of Nigerian animal health workers towards the elimination of the disease in the country.

Table 1: Respondents' Demographic Characteristics ( $n=446)$

\begin{tabular}{ll}
\hline Variable description & $\mathrm{N}(95 \% \mathrm{Cl})$ \\
\hline $\begin{array}{l}\text { Gender } \\
\text { Female }\end{array}$ & $290(60.4-69.4)$ \\
$\begin{array}{l}\text { Type of Occupation } \\
\text { Professional Veterinary Surgeon }\end{array}$ & $156(30.6-39.6)$ \\
Animal Health Technician (Support & $89(16.3-24.0)$ \\
personnel) & \\
Years of Experience & \\
$\begin{array}{l}\text { 1-10 years } \\
\text { 11-20 years }\end{array}$ & $156(30.6-39.6)$ \\
More than 20 years & $178(35.3-44.6)$ \\
Geopolitical Zone of Operation & $112(21.2-29.4)$ \\
North-Central & \\
North-West & $94(17.4-25.2)$ \\
North-east & $80(14.5-21.8)$ \\
South-West & $71(12.6-19.7)$ \\
& $76(13.7-20.9)$
\end{tabular}

\section{Materials and Methods}

The geographical focus of this present study included the 6 geopolitical zones of Nigeria. Nigeria is situated between latitudes $4^{\circ}$ to $14^{\circ} \mathrm{N}$ and longitudes $2^{\circ} 3^{\prime}$ and $14^{\circ} 30^{\prime} \mathrm{E}$. The sampling method adopted for the questionnaire survey was a simple random sampling technique, and the inclusion criteria for all respondents was that they all had to be practicing veterinarians or paravets working in Nigeria. Questions were asked about perceived national epidemiology and socioeconomic importance of the disease, preparedness towards disease control and elimination as well as animal disease reporting system and its suitability for PPR elimination. Data obtained were collated and analyzed using Microsoft Excel Spreadsheets Data and SPSS version 21 .

\section{Results and Discussion}

A total of four hundred and forty six (446) animal health workers participated in the survey which comprised veterinary surgeons and technicians from the six geopolitical zones of the country and with varying durations of professional experience (Table $1)$. Out of the listed common small animal diseases, $126(28.25 \%)$ respondents considered PPR as the most important small ruminant disease in Nigeria (Figure 1). It was revealed that only $40 \%$ have received PPR vaccination request since they began

practice. Results also showed that 259 (57.8\%) were aware of the ongoing FAO-OIE global eradication programme against PPR, with information sources being internet (55\%), print media (12\%), professional colleagues (32\%) and television (1\%). Study respondents were of the opinion that PPR eradication and control was the responsibility of animal health workers (67\%), Veterinarians (29\%), technologists (4\%) and government (0\%). Animal health workers were also convinced that Nigeria has the needed veterinary manpower, technical know-how and access to the requisite funding needed for instituting an effective PPR campaign. However, it was reported that the country lacks appropriate veterinary infrastructure, diagnostic and vaccine production capacity and animal disease surveillance and reporting system to eliminate the disease on or before 2030 (Table 2).

This is the first report assessing the awareness of concerned stakeholders on the global PPR eradication programme and it clearly reveals that 
South-East

South-South
71(12.6-19.7)

$54(9.2-15.5)$ not all concerned stakeholders are aware of the eradication programme.

\begin{tabular}{|c|c|c|c|}
\hline & Agree $(95 \% \mathrm{Cl})$ & Undecided $(95 \% \mathrm{Cl})$ & Disagree $(95 \% \mathrm{Cl})$ \\
\hline $\begin{array}{ll}\text { Adequate } & \text { veterinary } \\
\text { Infrastructure } & \end{array}$ & 73(13.1-20.1) & $31(4.8-9.7)$ & $342(72.5-80.5)$ \\
\hline $\begin{array}{l}\text { Adequate veterinary man- } \\
\text { power }\end{array}$ & $276(57.2-66.4)$ & $54(9.2-15.5)$ & $116(22.0-30.3)$ \\
\hline $\begin{array}{l}\text { Adequate government } \\
\text { funding capacity }\end{array}$ & $308(64.5-73.3)$ & $98(18.2-26.1)$ & $40(6.5-12.0)$ \\
\hline $\begin{array}{l}\text { Adequate commitment of } \\
\text { government }\end{array}$ & $27(4-8.7)$ & $134(25.8-34.5)$ & 285(59.3-68.4) \\
\hline $\begin{array}{l}\text { Adequate disease reporting/ } \\
\text { surveillance }\end{array}$ & $45(7.5-13.3)$ & $71(12.6-19.7)$ & $330(69.7-78.0)$ \\
\hline $\begin{array}{l}\text { Adequate training of animal } \\
\text { health workers }\end{array}$ & $285(59.3-68.4)$ & $71(12.6-19.7)$ & $89(16.3-24.0)$ \\
\hline $\begin{array}{l}\text { Optimum diagnostic } \\
\text { capacity }\end{array}$ & $86(15.7-23.3)$ & $88(16.1-23.7)$ & $272(56.3-65.5)$ \\
\hline $\begin{array}{l}\text { Optimum vaccine } \\
\text { production capacity }\end{array}$ & $90(16.6-24.2)$ & $121(23.1-31.5)$ & $235(47.9-57.4)$ \\
\hline
\end{tabular}

Although the lack of proper documentation of outbreaks makes it difficult to quantify the extent of the disease burden; the significance of PPR agrees with the perspectives of Shamaki (2012) and Fadiga et al., (2013), who stated that PPR is a common occurrence and cause of significant losses to farmers in Nigeria. For this reason, there is presently a global collaborative effort to achieve eradication of the disease (Anderson et al., 2011). Notwithstanding the impossibility of independently accessing vaccination coverage, the low vaccination request reported in this study will lead to low vaccination coverage. This would most likely constitute a big setback for any proposed PPR elimination campaign because an effective

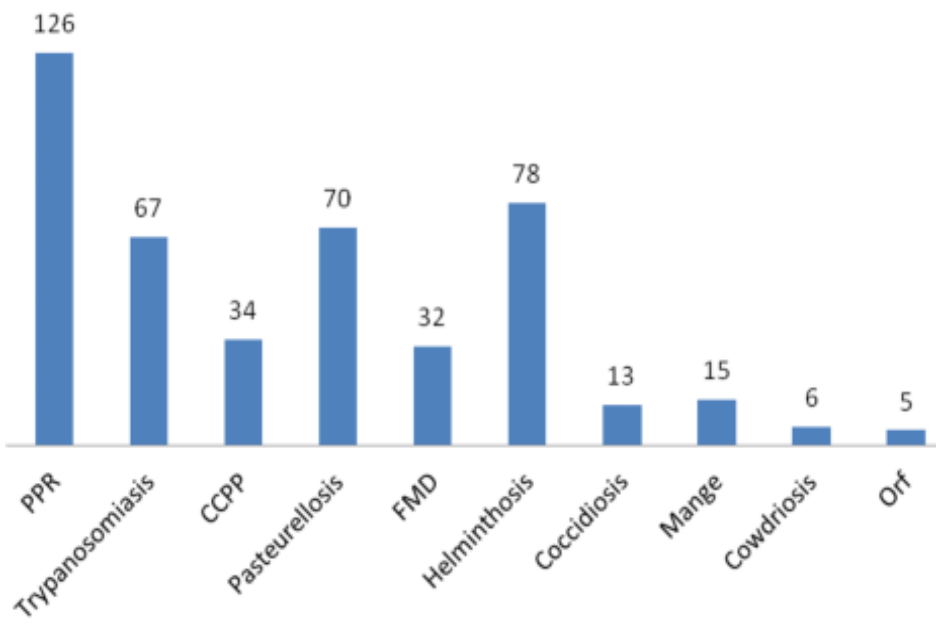

Figure 1: Perceptions of importance of selected small ruminant diseases in Nigeria

mass vaccination means $80 \%$ of the small ruminant population must be reached in a coordinated and timely manner (Singh, 2012). Poor diagnostic capacity, inadequate veterinary infrastructure and inadequate government commitment show the global urgency to improve veterinary infrastructure and services in disease endemic countries, as opined by Modisane (2009) and Pradere (2014). As reported in India, the production of rapid diagnostic kits will be of use in prompt diagnosis (Singh et al., 2009). The country's inadequate PPR vaccine production output might be a reason why previous efforts to control the disease yielded little result in Nigeria. This is in agreement with Fadiga et al. (2013), who observed that for the year 2008; Nigeria's vaccination coverage was just about $0.33 \%$ of the total population of small ruminant livestock in the country. Poor disease reporting status is similar to reports from other countries (Singh \& Bandyopadhyay, 2015). This will lead to outbreaks as it has occurred over the years in Nigeria. Nevertheless, a decline of more than $75 \%$ outbreaks can be achieved with an organized mass vaccination campaign in the country (Singh, 2012). 
In conclusion, it is believed that the findings from this present work will help to provide a framework for future research and also help to inform coordination of a PPR control and elimination programme in Nigeria.

\section{Acknowledgment}

The authors appreciate the Commonwealth Scholarship Commission who provided scholarship and funding for the study at the University of Edinburgh. We also wish to acknowledge Dr. Ewan MacLeod, Prof. Michael Thrusfield, Prof. Paul Gibbs, Drs. Liz Grant, Kim Picozzi, Jena Fyfe, and the support staff of the Global Health Academy, University of Edinburgh.

\section{References}

Albina E, Kwiatek O, Minet C, Lancelot R, Almeida R \& Libeau $G$ (2013). Peste des petits ruminants, the next eradicated animal disease? Veterinary Microbiology, 165(1-2): 38-40.

Anderson J, Baron M, Cameron A, Kock R, Jones B, Pfeiffer D, Mariner J, McKeever D, Oura C, Roeder P, Rossiter P \& Taylor W (2011). Rinderpest eradicated; What Next? Veterinary Record, 169(1): 10-11

Baron M, Parida S \& Oura C (2011). Peste des petits ruminants: A suitable candidate for eradication? Veterinary Record, 169(1): 1621.

Fadiga M, Jost C \& Ihedioha J (2013). Integrated Animal and Human Health Management Project Final Report. Financial Costs of Disease Burden, Morbidity and Mortality from Priority Livestock Diseases in Nigeria (D Baker, I Okike, editors), International Livestock Research Institute, Ethiopia.

FAO - OIE Global strategy for the control and eradication of PPR (2015). http://www.fao.org/3/a-i4460e.pdf, retrieved 03-05-2016.

Modisane BM (2009). Field Services: Eradication and control of animal diseases. Onderstepoort Journal of Veterinary Research, 76(1): 115121.

Pradere JP (2014). Improving animal health and livestock productivity to reduce poverty. Revue Scientifique et Technique (Paris), 33(3): 735-744.

Shamaki D (2012). Peste des petits ruminants (PPR): A Bottle-Neck to Caprine and Ovine Production in Nigeria. A Paper Presented at the 2012 Veterinary Council of Nigeria (VCN) Professional Continuing Education Seminar, held at Federal University of Agriculture, Abeokuta (FUNAAB), Nigeria, 12' September, 2012.

Singh RK, Balamurugan V, Bhanuprakash V, Sen A, Saranavan P \& Yadav MP (2009). Possible control and eradication of peste des petits ruminants from India: Technical aspects. Veterinaria Italiana, 45(3): 449-462.

Singh RP (2012). Strategic control of peste des petits ruminants. In: Veterinary and Livestock Sector : A Blueprint For Capacity Building Sudhi (R Garg, editor). New Delhi: Satish Serial Publisher. Pp 327-345.

Singh RP \& Bandyopadhyay SK (2015). Peste des petits ruminants vaccine and vaccination in India: Sharing experience with disease endemic countries. Virus Disease, 10.1007/s13337-015-0281-9.

Torsson ET, Berg M, Mtui-Malamsha N, Swai ES, Wensman JJ \& Misinzo G (2016). History and current status of peste des petits ruminants virus in Tanzania. Infection Ecology and Epidemiology, doi:10.3402/iee.v6.32701. 